【論文】

\title{
フイラー添加高分子材料に拧ける \\ 短時間絶縁破壊の破壊電圧予測 \\ Prediction of Instantaneous Dielectric Breakdown Voltage of Filler Dispersed Polymer Composites
}

\author{
曽我宏輔 ${ }^{*}$ 齊藤卓志 ${ }^{*}$ 石川和紀 ${ }^{* *}$ 川口達也 ${ }^{*}$ 佐藤勲* \\ Kosuke Soga*, Takushi Saito*, Kazunori Ishikawa**, Tatsuya Kawaguchi* and Isao Satoh*
}

セラミックスフィラー添加高分子複合材料はその熱伝導率の高さと電気絶縁性からパ ワーデバイス周りで使用されている。しかし，熱伝導率を上げるためにフィラー含有率を増 加させると絶縁破壊電圧が低下寸る傾向がある。よつて, この材料の絶縁破壊特性を把握す ることは, より性能の高い材料設計に必須である。そこで本研究では，セラミックスフィラ 一添加高分子複合材料の絶縁破壊特性を数值シミュレーションにより求め, 実験により得ら れた窒化ホウ素およびボイドを含むフィルム状の複合材料の絶縁破壊電圧との比較を行っ た.数值シミュレーションでは実際の材料の断面をSEMにより観察した二次元画像を用い, 実験と同様に試料の厚さ方向にわたる絶縁破壊現象をモデル化することで，材料中に含まれ るボイドが絶縁破壊の起点となる様子が示された。得られた結果より, 本研究で想定した材 料では, 試料厚さ方向のボイド率が絶縁破壊電圧に最も大きな影響を与える要素であると示 唆された.

Composite polymer material containing ceramic filler is often used for an electric power device because it has high thermal conductivity and good electric insulation simultaneously. However, the dielectric breakdown voltage of the composite material tends to be lowered by increasing the volume ratio of the ceramic fillers so as to improve the thermal conductivity. Therefore, understanding of the phenomena of dielectric breakdown in the composite material is important to obtain the knowledge for better material design. In this study, the dielectric breakdown voltage of the filler containing composite polymer material was numerically simulated and the obtained results were compared with the data of the sample containing Boron-Nitride and voids (inevitability included during the sample preparation). Microstructure of the composite material was analyzed by SEM and the obtained two dimensional images were used for the numerical simulation of the dielectric breakdown. The dielectric breakdown phenomena of the composite polymer film were successfully performed, and the propagation phenomena of the breakdown in the film thickness direction was simulated. The results showed that the voids in the composite was the initiation point of the breakdown. From the obtained results, it was indicated that the most influential factor of the dielectric breakdown in the used system was the void ratio in the thickness direction.

[Keywords: Composite material, Dielectric breakdown, Numerical simulation]

\section{1. 緒言}

* 東京工業大学 工学院機械系,

干152-8552 東京都目黒区大岡山 2-12-1.

School of Engineering Department of Mechanical Engineering, Tokyo Institute of Technology, 2-12-1 Ookayama, Meguro-ku, Tokyo. 152-8552

FAX: +81-3-5734-3917 E-mail: tsaito@mep.titech.ac.jp

** 日本化薬株式会社,

干100-0005 東京都千代田区丸の内 2-1-1

Nippon Kayaku Co., Ltd., 2-1-1,Marunouchi, Chiyoda-ku, Tokyo. 100-0005.

FAX: 03-3237-5431

E-mail: kazunori.ishikawa@nipponkayaku.co.jp
セラミックスフィラーを含んだ樹脂材料は樹脂単体と 比較して熱伝導率が高く, 電気絶縁性と高い熱伝導率の 両立が求められるパワーデバイス周りへの利用が期待さ れている。 しかしフィラーとして用いられる窒化ホウ素 やアルミナなどの熱伝導率は樹脂材料に比べ非常に高い ものの, その絶縁破壊電圧はポリイミドやポリアミドと いったエンジニアリングプラスチックスに比べると低い. このため, 熱伝導率向上を狙ってフィラー含有量を増加 
させると耐電圧の低下が生じる懸念がある $[1,2] . つ ま り ，$ 耐電圧の低下を抑制しつつ熱伝導率の向上を図るために は，適切な物性予測が重要となる.

フィラー添加高分子材料の絶縁破壞電圧や熱伝導率は, フィラーや樹脂単体での物性, フィラー含有率のみによ り決まるものではなく, フィラーの形状や配置にも大き く影響される. 熱伝導率については物性の予測式として Bruggeman モデル[3]や Hatta-Taya モデル[4, 5]が利用でき る.しかし,これらの手法ではフィラーの空間干渉を考慮 しておらず, 特に高充填の場合に実際の熱伝導率に比べ 低く見積もられる傾向にある. そこで, 数值シミュレーシ ヨンにより熱伝導率を求める試みがなされておりフィラ 一配置の影響も考慮した熱伝導率が予測可能となりつつ ある[6,7]. 一方, 絶縁破壊のシミュレーションについて は, 長時間高電圧下にさらされた高分子材料に発生する トリー形状の局所絶縁破壊の進展を対象とした報告[8]は 存在するが，フィラー添加高分子材料において生じる瞬 時的な絶縁破壊の予測を行っている研究は著者の知る限 り存在しない. 絶縁破壊は材料中の一点で起こる現象で あるため, 耐電圧は局所的な材料分布に大きく影響され る. 樹脂中に分散されているフィラーの力学的特性は樹 脂のそれと大きく異なり, また光を通さないため, 超音波 や光を用いた検查手法では, 非破壊で材料分布を得るこ とは難しい.フィラー含有率と絶縁破壊電圧の関係を実

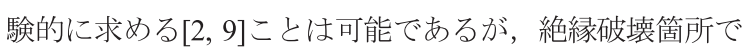
は通電によるジュール発熱により, 樹脂が炭化・蒸発する ため絶縁破壞箇所の特徵を後から解析することは困難で ある.

そこで, 本研究では数值シミュレーションにより直流 電圧下におけるフィラー添加高分子材料の絶縁破壊にお ける破壊電圧の予測を行うとともに, フィラー添加によ る破壊電圧低下のメカニズムについて考察した. 実験に よりフィラー添加高分子材料の絶縁破壞電圧を取得した 後, その試料の断面画像よりフィラー配置のモデル化を 行った. 得られたモデルに対し数值シミュレーションに

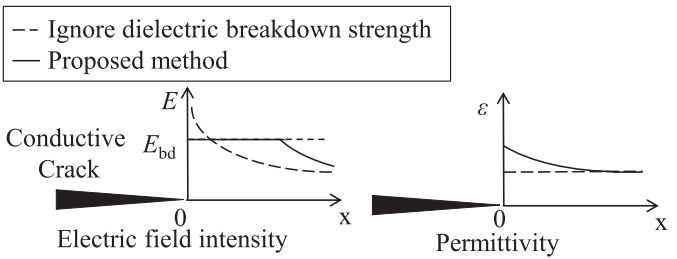

Fig. 1 Schematic image of the electric field intensity and the permittivity around the tip of conductive crack
より絶縁破壊電圧を予測し, 実験結果との比較を行った. なお本研究では, 絶縁破壊強度超過箇所ではその材料の 破壊強度を維持すると仮定した. また, 解析手法の妥当性 を検証するために予めき裂を与えた高分子フィルムの絶 縁破壊電圧と, き裂深さの関係の比較を行ったので併せ て報告する．

\section{2. 計算モデル}

長時間かけて起こるトリーの成長のような絶縁破壊シ ミュレーションでは破壊強度超過箇所の誘電率を高く設 定し（例えば 1000 倍など），その箇所における電界強度 を低下させる手法がとられている [8-11]. しかし，短時間 のうちに生じる絶縁破壞現象にこのモデルを導入すると， 破壊電圧が低く見積もられる䀣念がある。これは誘電率 差により破壊強度超過箇所周辺で非常に高い電界が生じ, 絶縁破壞強度超過箇所が雪崩的に拡大寸るためである. そこで, 本研究では絶縁破壊強度超過筒所では, その材料 の絶縁破壊強度 $E_{b d}$ が維持されると仮定した. 例えば導電 性クラックの先端における電界強度分布並びに誘電率分 布をそれぞれ図 1 に示す，図中縦軸はそれぞれ電界強度 及び誘電率を表しており，材料の絶縁破壊強度を考えな い場合, 誘電率のミスマッチにより図中点線のようにき 裂先端において電界強度は無限に高くなる. 一方, 提案手 法では黒線のように電界強度を維持させるため, 誘電率 は高くなるように設定している.

この局所絶縁破壊強度超過箇所が電極間を連続的につ ながった時を絶縁破壞と仮定し，その時点での電位差を 絶縁破壊電圧とした. よって, 一定の電圧印加時における 破壊強度超過箇所を定常的に解き, 印加電圧を逐次増加 させることで疑似的に短時間破壊をシミュレーションし た. 定常状態における電界分布 $\Phi$ は式(1)を有限差分法に より離散化し求め. 誘電率 $\varepsilon$ は, 提案手法に基づいて局所 の電界強度のスカラー值を式 $(2,3)$ により求め, これに対 する誘電率を式(4)で与えた。

$$
0=\varepsilon \nabla^{2} \phi
$$

$$
\begin{aligned}
& E_{x}=\frac{\partial \phi}{\partial x} \\
& E_{y}=\frac{\partial \phi}{\partial y}
\end{aligned}
$$

$$
E=\left(E_{x}^{2}+E_{y}^{2}\right)^{1 / 2}
$$




$$
\varepsilon_{\text {new }}=\left\{\begin{array}{cc}
\varepsilon_{0} & \left(E<E_{b d}\right) \\
\varepsilon_{\text {old }}\left(\frac{9 E_{b d}+E}{10 E_{b d}}\right) & \left(E>E_{b d}\right)
\end{array}\right.
$$

ここで，Eは電界強度であり， $\varepsilon_{0}$ は初期の誘電率であり， $\varepsilon_{\text {old }}, \varepsilon_{\text {new }}$ はそれぞれ現在および次の計算ステップでの誘電 率となる. 局所的な誘電率の変化については, 求められた 電界分布に基づいて誘電率を更新する作業を電界および

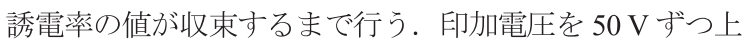
昇させながら，これを繰り返すことで, 絶縁破壊に至る電 圧をシミュレーションにより推定した。

\section{3. き裂を有する高分子フィルムの絶縁破壊}

\section{1 実験方法}

フィラー添加高分子材料では母材となる樹脂とフィラ 一に加え, 製造工程で不可避にボイドが混入するため, 電 界分布や破壊経路が複雑となる. そこで, 提案手法を検証 するため, き裂を有する高分子フィルムの絶縁破壞シミ ュレーションを実験結果と比較した。実験では優れた絶 縁性能, 力学特性を持つため, 電子機器のフレキシブル基 板として利用されているポリイミドフィルム（東レ・デュ ポン社製カプトンフィルム) を供試材料とした. フィルム 厚さは $50 \mu \mathrm{m}$ であり, 沿面放電を防ぐために試料は 100 $\mathrm{mm} \times 100 \mathrm{~mm}$ の大きさで作成した. なお，このポリイミド フィルムの絶縁破壊強度は $400 \mathrm{kV} / \mathrm{mm}$ である. 図 2 (a), (b) に示寸ように，試料には剃刀を用いて予深さの異なる き裂を与えた。与えたき裂の深さは絶縁破壞試験後に光 学顕微鏡を使った断面観察により求めた。電極は直径 30 $\mathrm{mm}$ のステンレス棒とし, き裂を挟むように試料の上下に 配置した(図 3(a))。なお，電極端部は紙やすりで研磨し， 図3(b)に示すような良好な接触を保証した。

電源として, 高電圧直流電源(松定プレシジョン製HAR20N15)を用い，0 -20 kV の直流電圧を印加した. 実験で は $0 \mathrm{~V}$ から $1000 \mathrm{~V} / \mathrm{s}$ で電位差を増大させ, 絶縁性能が失 われた際の電位差を破壊電圧として記録した。

\section{2 解析条件}

実験結果との比較のため図 4 に示寸ように上下を電極 で挟まれた高分子に対して，き裂に相当する空気層を挿 入し, 絶縁破壊電圧に与えるき裂深さの影響を計算によ
り求めた. 計算領域は厚さ $50 \mu \mathrm{m}$, 幅 $50 \mu \mathrm{m}$ の二次元とし た.き裂は厚さ方向に与え, 深さは 5 45 $\mu \mathrm{m}$ とした. 計算 に用いた物性值を表 1 に示す。

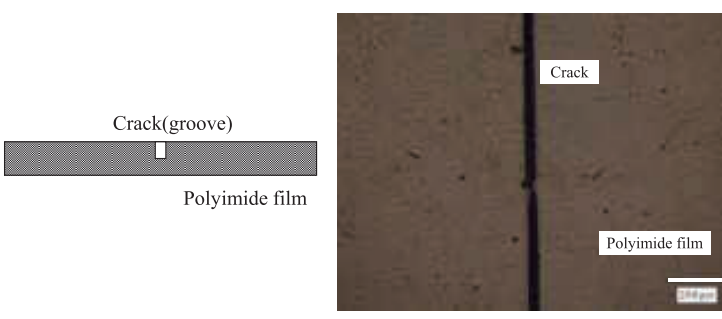

(a)

(b)

Fig. 2 Schematic and microscopic image of the crack given to the polymer film, (a) Cross section image of the film, (b) surface image of the film

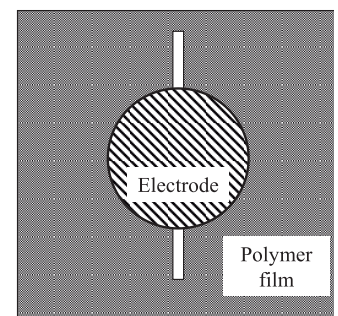

(a)

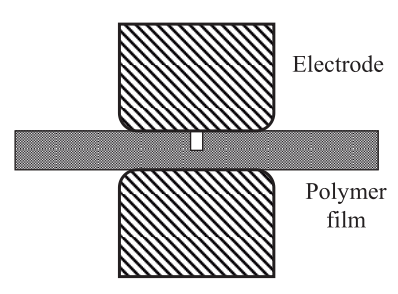

(b)
Fig. 3 Schematic image of electrode arrangement, (a) surface image and (b) cross section image of cylindrical electrode

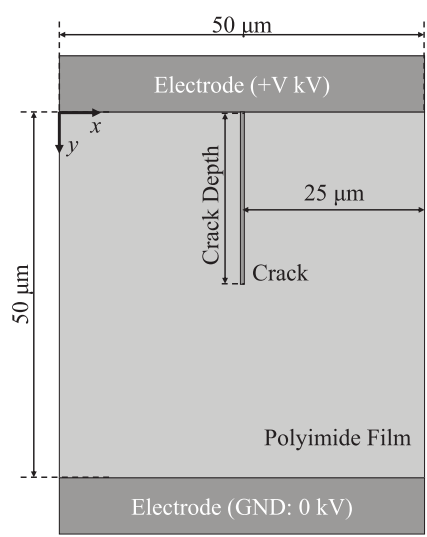

Fig. 4 Schematic image of simulation model for crack depth effect on the dielectric breakdown voltage

Table 1 Electric properties of dielectric breakdown simulation of crack inserted polymer film

\begin{tabular}{|c|c|c|}
\hline & $\begin{array}{c}\text { Initial } \\
\text { relative } \\
\text { permittivity } \\
\varepsilon_{0}\end{array}$ & $\begin{array}{c}\text { Dielectric breakdown } \\
\text { strength }(\mathrm{kV} / \mathrm{mm})\end{array}$ \\
\hline Crack (air) & 1.0 & 3.0 \\
\hline Polyimide & 4.0 & 400 \\
\hline
\end{tabular}




\section{3 実験及び解析結果}

図 5 にき裂の断面画像の一例を示寸，挿入したき裂は 斜めに入っているが，き裂梁さは試料表面からの $y$ 軸方 向の長さと定義した. 実験で挿入したき裂の深さは 5 45 $\mu \mathrm{m}$ である. 図 6 にき裂深さ $10 \mu \mathrm{m}$ におけるシミュレーシ ヨン結果を示寸. 図中には, 各電位差において絶縁破壞強 度超過箇所が赤色で示されている. 電位差の増加により 絶縁破壞強度超過箇所は拡大し, $17.3 \mathrm{kV}$ 印加時に全路破 壊に至った。図 7 に実験結果とシミュレーションにより 求めた, き裂深さと絶縁破壞電圧の関係を示す. 実験結果 および計算結果はよく一致しており, 直流電圧下におけ る絶縁破壊電圧の推定に対し, 提案手法によるシミュレ ーションは適切であると考えられた。
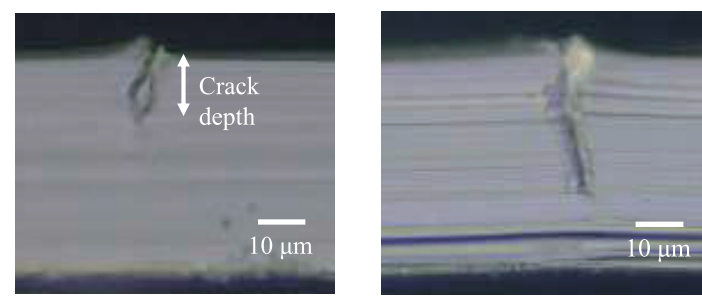

Fig. 5 Microscopic cross section image on the crack

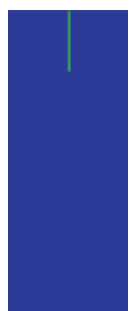

$0 \mathrm{kV}$

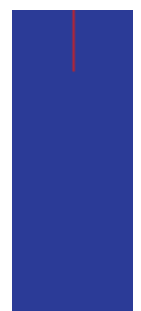

$5.0 \mathrm{kV}$

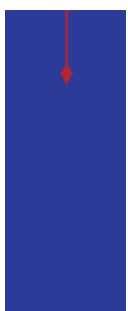

$10.0 \mathrm{kV}$

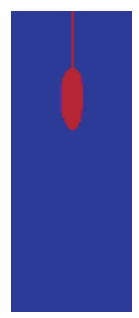

$15.0 \mathrm{kV}$

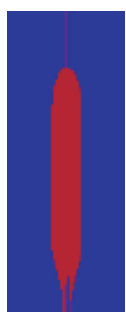

$17.3 \mathrm{kV}$
Fig. 6 Propagation of the dielectric breakdown inside of polyimide with a crack, the crack depth was $10 \mu \mathrm{m}$, blue, green and red colors are polymer, void and partial discharge area, respectively.

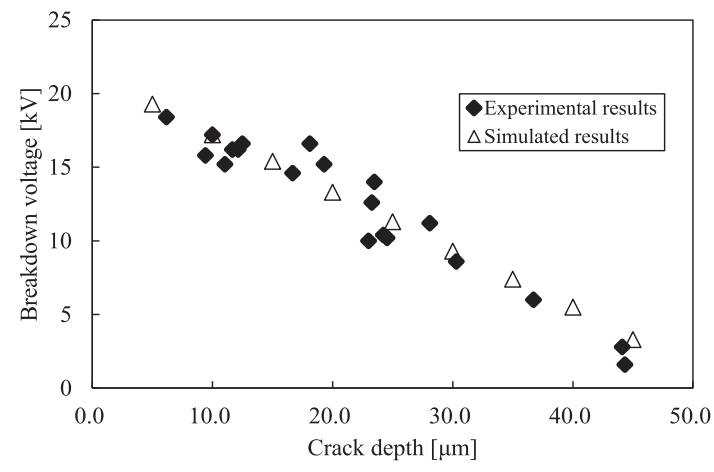

Fig. 7 Comparison of the simulated and experimental results of the breakdown voltage at different crack depth

\section{4. フィラー添加高分子材料の絶縁破壊}

\section{1 実験方法}

実験に用いた試料は樹脂に窒化ホウ素のフィラーを分 散させた複合材料である. 絶縁破壊電圧は材料内の局所 的なフィラーやボイドの配置により大きく変化する．そ のため, 同一の試料内であっても場所によって破壊電圧 に大きな差が生じる。この材料分布の偏りは試料調製時 に生じる樹脂流動が原因として考えられる. 今回使用し た試料はもともと $200 \mathrm{~mm}$ 角, 厚さ $150 \mu \mathrm{m}$ のシート状で あり, 試料中心部は端部に比較し破壊電圧が高くなる傾 向が見られた. そこで, 同一の試料より異なる箇所の試験 片を切り出し, 絶縁破壊試験を実施した。 なお, 絶縁破壞 試験は前節で述べたポリイミドフィルムの絶縁破壊電圧 測定と同様の方法で行うが, き裂は与えなかった. また， 破壞箇所を限定するため, 図 8 に示寸とおり, 試料との電 圧印加体積が小さくなる点接触電極を上部電極に用いた. なお，下部電極は，前節と同じ直径 $30 \mathrm{~mm}$ の円柱電極と した.

破壊試験後に各破壊箇所近傍で, CP(クロスセクション ポリッシヤ)処理を実施し，SEM を用いた断面観察を行っ た。また，取得した断面画像を輝度值により樹脂，フィラ 一, ボイド (空気) の三相に分類し, 数值シミュレーショ ンにおける対象モデルとした.

\section{2 計算条件}

実験によって得た破壊電圧と断面画像に基づいてシミ ユレーション予測した破壊電圧の比較を行った。実験に よって得た断面画像の一例を図 9(a)に, 数值シミュレーシ ヨンのために三值化した材料分布を図 9(b)に示す.三值化 した画像は図 10 に示寸ように $y$ 方向に厚さ $150 \mu \mathrm{m}, x$ 方 向に幅 $400 \mu \mathrm{m}$ とし, 図中 $y$ 方向に電位差を与えた. 表 2 に計算に用いた物性を示寸.

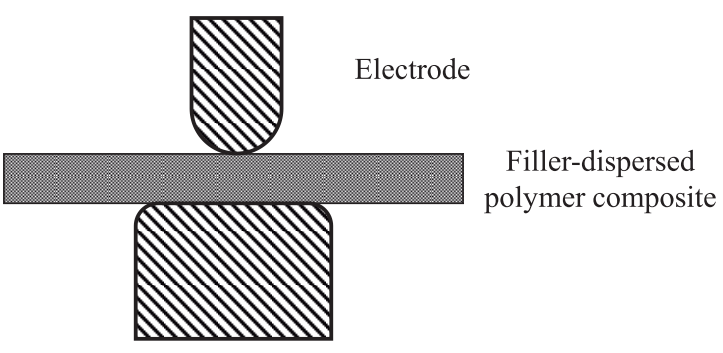

Fig. 8 Side view of point contact electrode 


\section{3 結果と考察}

図 11 に三值化した断面画像（図 11(a),(b)）およびシミュ レーションにより求めた全路絶縁破壊時の絶縁破壊強度 超過箇所の分布（図 11(c),(d)) を示す.ここで(a)と(c), (b) と(d)はそれぞれ対応しており, 初期状態と絶縁破壊時の 状態を表す. 図中の青は樹脂, 白はフィラー, 緑はボイド, 赤は絶縁破壊強度超過箇所を示している. 図 11(a), (c)は試 料端部の破壊電圧が低い部分から取得した試験片であり， $17 \mathrm{kV} / \mathrm{mm}$ の電界強度で絶縁破壊した。一方, 図 11(b), (d) に示される試料中心付近の試験片については, $42 \mathrm{kV} / \mathrm{mm}$ という高い值になった. 図 11(c), (d)の比較により, ボイド 率が低く絶縁破壊強度が高い試料(図 11(d))では全領域に わたって絶縁破壊が生じたことが示された。つまり, 材料 が本来有していた絶縁破壊強度を最大限利用した結果と

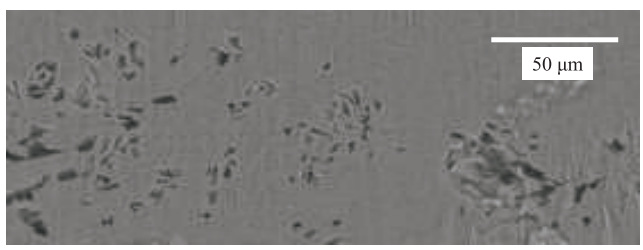

(a)

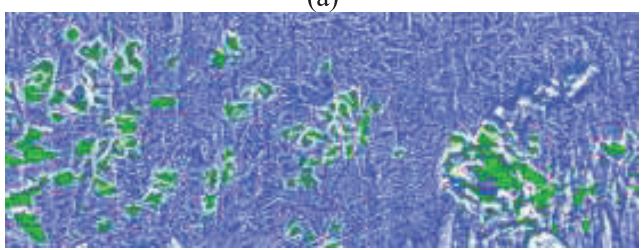

(b)

Fig. 9 Cross section image of filler-dispersed composite (a) SEM (b) trinary image of material distribution, blue, white and green colors are polymer, filler and void, respectively.

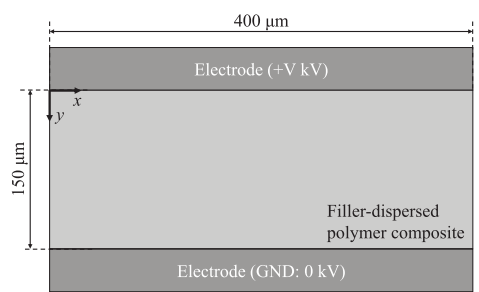

Fig. 10 Schematic image of simulation model for dielectric breakdown of composite

Table 2 Electric properties for dielectric breakdown simulation of filler dispersed polymer composites

\begin{tabular}{|l|c|c|}
\hline & $\begin{array}{l}\text { Relative } \\
\text { permittivity }\end{array}$ & $\begin{array}{l}\text { Dielectric breakdown } \\
\text { strength }(\mathrm{kV} / \mathrm{mm})\end{array}$ \\
\hline Polymer & 4.0 & 160 \\
\hline Ceramics Filler & 4.0 & 30 \\
\hline Void (air) & 1.0 & 3.0 \\
\hline
\end{tabular}

いえる. 図 12 に絶縁破壊電圧が低かった試料における全 路絶縁破壊箇所の拡大図を示す。なお，図 12 において絶 縁破壊は黒枠内で起きており，ボイドの周辺を黄線で縁 取っている．絶縁破壊電圧は，樹脂，フィラー，ボイドの 順に高く，ボイドから先に絶縁破壊強度を迎える. 厚さ方 向に多くのボイドがある箇所ではボイドが絶縁破壊強度 に達し，樹脂層とフィラーが受け持つべき電界強度が上 昇したため，樹脂及びフィラーは他の箇所より早く絶縁 破壊強度を迎えた。しかし，厚さ方向にボイドが少ない箇 所では絶縁破壊強度に達していないことから同一試料内 で絶縁破壊電圧に差が出る主要因はボイドであり，ボイ ド分率が厚さ方向に高い箇所ほど絶縁破壊が早く生じる 様子をシミュレーション出来たと言える.

フィラー添加高分子材料における絶縁破壊電圧の実験 結果と計算結果の比較を図 13 に示寸。絶縁破壊電圧の計 算結果は実験結果よりやや高い值となるが，破壊電圧の

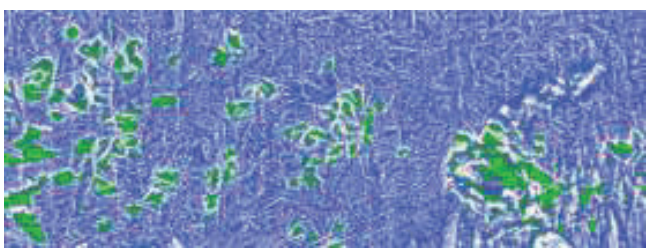

(a)

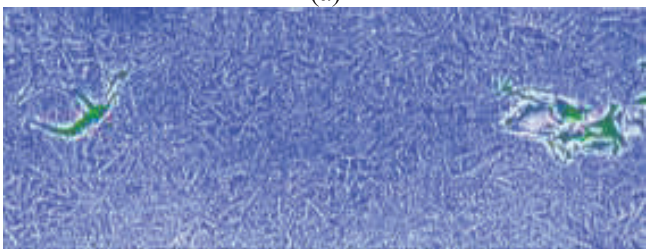

(b)

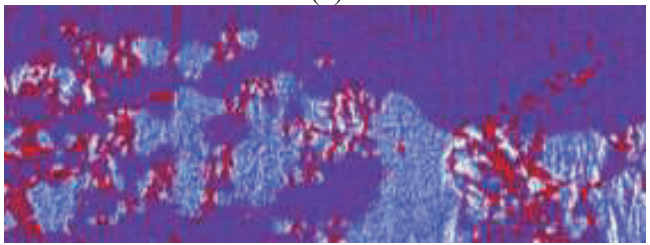

(c)

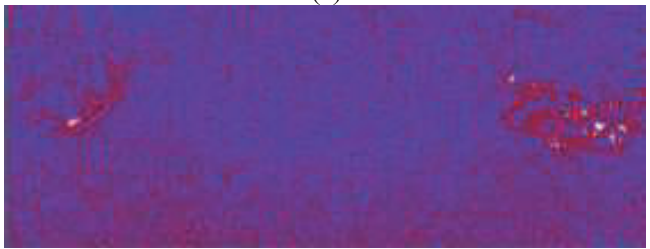

(d)

Fig. 11 Microscopic image of the composite material overlapped with the partial discharge region: (a) and (b) show initial state, in where white, blue and green are filler, polymer and void, respectively (c) and (d) show the over breakdown strength area: red color is the over breakdown strength area. 
傾向は一致している. 今回のシミュレーションでは断面 画像をもとに破壊電圧を推定したため, 全路破壊の経路 は断面画像内の二次元空間に限られている.しかし, 実際 の全路破壊は三次元的に形成され，今回のシミュレーシ ヨンでは発見できなかった, より低い電压で全路破壊を 起こす経路の存在が予想される. そのため, シミュレーシ ヨンにより予測した破壊電圧は高くなったと考えられる.

\section{5. 結言}

本研究では，実験及び数值シミュレーションの比較に より, フィラー添加高分子材料における絶縁破壊電圧低 下の要因を検討した。局所的な絶縁破壊強度超過箇所で はその破壊強度を維持し続けるとした計算手法を開発し， き裂を有する高分子フィルム材料に適用することで，提 案手法の妥当性を検証した. この手法を用いてフィラー 添加高分子材料の断面画像に基づいて絶縁破壊にいたる 状況を数值シミュレーションし, ボイドを起点として絶 縁破壊強度超過箇所が拡大寸ることで, 全路破壊に至る 様子を再現した. また, フィルム厚さ方向におけるボイド

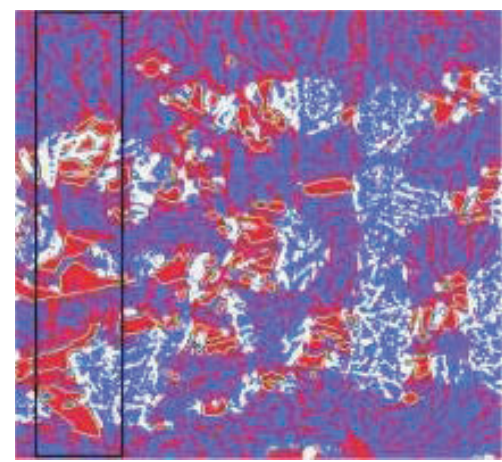

Fig. 12 Magnified image of the fully discharged region, in where white, blue and red colors are filler, polymer and PD area of polymer and filler, respectively. The yellow lines indicate shape of voids.

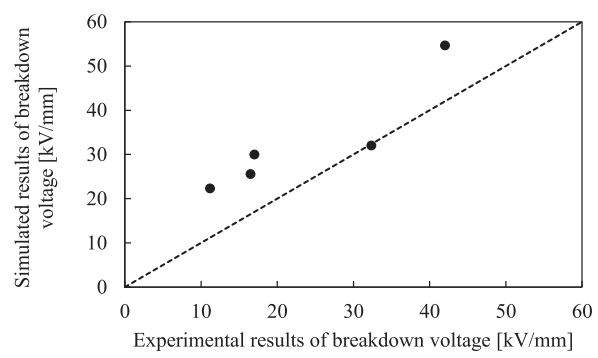

Fig. 13 Comparison of the simulated and experimental results of the breakdown voltage
含有率が絶縁破壊電圧に大きく影響することを指摘した.

\section{参考文献}

[1] C. P. Wong, R. S. Bollampally; "Thermal conductivity, Elastic Modulus and Coefficient of Thermal Expansion of Polymer Composites Filled with Ceramic Particles for Electronic Packaging", JAPS, 74 (1999) 3396-3403.

[2] H. Li, G. Liu, B. Lou, W. Chen, S. Chen; "Dielectric properties of Polyimide/ $\mathrm{Al}_{2} \mathrm{O}_{3}$ hybrids synthesized by in-situ Polymerization", Materials Letters 61 (2007) 1507-1511.

[3] D.A.G Bruggeman; "Calculation of various physical constants of heterogeneous substances", I. Dielectric constants and conductivities of the mixed body of isotropic substances, Ann. Phys., (Leipzig) 24 (1935) 636-791.

[4] H. Hatta, M. Taya; "Effective thermal conductivity of a misoriented short fiber composite", J. Appl. Phys. 58 (7) (1985) 2478-2486.

[5] H. Hatta, M. Taya; "Equivalent inclusion method for steady state heat conduction in composites", Int. J. Eng. Sci., 24 (7) (1986) 1159-1172.

[6] R.F. Hill, P.H. Supanic; "Thermal conductivity of plateletfilled polymer composites", J. Am. Ceram. Soc., 95 (4) (2002) 851-857.

[7] D. Kumlutas, I.H. Tavman; "A numerical and experimental study on thermal conductivity of particle filled polymer composites", J. Thermoplast. Compos. Mater. 19 (2006) 441-455.

[8] K. C. Pitike, W. Hong; "Phase-field method for dielectric breakdown in solids", J. Appl. Phys., 115, 044101(2014)

[9] Z. Whang, T. Iizuka, M. Kozako, Y. Ohki, T. Tanaka; "Development of epoxy/BN composites with high thermal conductivity and sufficient dielectric breakdown strength part II- breakdown strength", IEEE TDEI, 18, No.6(2011) 1973-1983.

[10] K.Wu, Y. Suzuoki, T.Mizutani, H.Xie; "A novel physical model for partial discharge in narrow channels", IEEE, TDEI, vol.6, no. 2, (1999) 181-190.

[11] C. Gao, N. Noda, T. Zhang; "Dielectric breakdown model for a conductive crack and electrode in piezoelectric materials", Int. J. Eng. Sci., 55(2006) 256-272.

[Received May 2, 2017, Accepted Jun.19, 2017] 